Review

\title{
Antibodies at work in the time of severe acute respiratory syndrome coronavirus 2
}

\author{
Kuttuvan Valappil Sajna*,**, Siya Kamat* \\ Department of Biochemistry, Indian Institute of Science, Bangalore, India
}

\section{A R T I C L E I N F O}

\section{Article History:}

Received 19 June 2020

Accepted 25 August 2020

\section{Key Words:}

convalescent plasma therapy

immunotherapy

monoclonal antibodies

nanobodies

SARS-CoV-2

\begin{abstract}
A B S T R A C T
In view of devastating effects of COVID-19 on human life, there is an urgent need for the licened vaccines or therapeutics for the SARS-CoV-2 infection. Age-old passive immunization with protective antibodies to neutralize the virus is one of the strategies for emergency prophylaxis and therapy for coronavirus disease 2019 (COVID-19). In this review, the authors discuss up-to-date advances in immune-based therapy for COVID-19. The use of convalescent plasma therapy as the first line of defense to treat severe acute respiratory syndrome coronavirus 2 (SARS-CoV-2) infection has been established, with encouraging results. Monoclonal antibodies (mAbs) that bind to the receptor-binding domain (RBD) of the SARS-CoV-2 spike protein or block the interaction between SARS-CoV-2 RBD and the human angiotensin-converting enzyme 2 receptor have been found to be very promising as a countermeasure for tackling the SARS-CoV-2 infection, and clinical trials are underway. Considering the counterproductive antibody-dependent enhancement of the virus, mAbs therapy that is safe and efficacious, even in people with underlying conditions, will be a significant breakthrough. In addition, emerging immunotherapeutic interventions using nanobodies and cellular immunotherapy are promising avenues for tackling the COVID-19 pandemic. The authors also discuss the implication of mAbs as mediators of cytokine storm syndrome to modify the immune response of COVID-19 patients, thus reducing the fatality rate of COVID-19 infection.
\end{abstract}

(c) 2020 International Society for Cell \& Gene Therapy. Published by Elsevier Inc. All rights reserved.

\section{Introduction}

The latest 21st century pandemic, coronavirus disease 2019 (COVID-19), by the etiological agent severe acute respiratory syndrome coronavirus 2 (SARS-CoV-2), has led to a worldwide disruption of human activities. Globally, as of August 21, 2020, SARS-CoV-2 has infected 22,536,278 people and led to 789,197 deaths, as reported by the World Health Organization [1]. The unprecedented clinical challenges posed by human-to-human transmission of SARSCoV-2 begin with a range of clinical manifestations, including fever, cough and dyspnea, with no or mild pneumonia. Severe cases present with dyspnea, hypoxia and $>50 \%$ pulmonary damage, requiring intensive care for respiratory support, whereas critical cases are characterized by respiratory and multi-organ failure. SARS-CoV is also known to cause the common complication of acute respiratory distress syndrome, thus requiring mechanical ventilation [2].

The high morbidity and mortality rates worldwide demonstrate that there seem to be differential responses in COVID-19 patients. The global imperative of the current hour is to rapidly develop

\footnotetext{
** Correspondence: Kuttuvan Valappil Sajna, PhD, Department of Biochemistry, Indian Institute of Science, Bangalore 560012, India.

E-mail address: sajnak@iisc.ac.in (K.V. Sajna).

* These authors contributed equally to this work.
}

immune therapy to prevent COVID-19 [3]. Hence, it is necessary to understand the immunological basis of this infection, the implications of which will offer better insight into the development of new therapies. Extracorporeal membrane oxygenation is one of the evolving strategies that can be utilized in treating patients with refractory hypoxemia and altered lung properties despite optimal conventional treatment, including mechanical ventilation [4]. Combining anti-viral and anti-inflammatory treatments is also being investigated. Repurposing drugs for COVID-19, with the challenge of appropriate dosage, remains an attractive treatment modality [5]. Many studies have also tried to investigate the function of glucocorticoids in modulating inflammation-mediated lung injury, thereby mitigating the progression of respiratory failure and mortality [6].

\section{SARS-CoV-2: the escape pathogen}

The first event in the chronology of SARS-CoV-2 infection is the virus binding to a host cell. The cytopathic virus utilizes its spike glycoprotein (S) located on its surface to bind with the angiotensin-converting enzyme 2 (ACE2) receptor for cell entry. Various research groups have targeted the receptor-binding domain (RBD) of SARS-CoV, SARS-CoV-2 and Middle East respiratory syndrome CoV (MERS-CoV) with neutralizing antibodies to combat the infection [7]. The S protein has two functional subunits: the S1 subunit mediates cell attachment, and the S2 
subunit is involved in the fusion of viral and cellular membranes [8]. SARS-CoV-2 principally targets airway, alveolar and vascular epithelial cells and lung macrophages, all of which express the ACE2 entry receptor. SARS-CoV-2, in combination with ACE2, is endocytosed by cells. As a result of the inability of ACE2 to regulate the renin-angiotensin system, blood pressure and electrolyte imbalances occur [9]. Furthermore, loss of ACE2 promotes accumulation of angiotensin II, which eventually activates A disintegrin and metalloproteinase 17 activity, perpetuating membrane shedding of ACE2, renin-angiotensin system overactivation and inflammation $[10,11]$.

Zhu et al. [12] investigated the morphogenetic process and cytopathic effect of SARS-CoV-2 infection in organotropic human airway epithelial cultures. It was observed that the virus infected both ciliated and secretory cells, because of which the authors suggest the possibility of the involvement of other receptors in addition to ACE2. This is because ACE2 is mainly expressed on ciliated epithelial cells of human lungs [12]. Viral infection and replication in upper respiratory tract epithelial cells induce pyroptosis. This inflammatory phenomenon of programmed cell death is commonly observed in SARS-CoV-infected cells too [13]. The epidemiology working group for novel COVID-19-infected pneumonia epidemic response reported the differential fatality rate in males and females, where the percentage of deaths was higher in males [14]. This correlates with the immunoregulatory functions of estrogen and testosterone [15]. A cellular serine protease, transmembrane protease serine 2 , is observed to process the $S$ protein and eventually contribute to host cell entry. Hence, transmembrane protease serine 2 is also a potential drug target that has attracted a lot of attention in the field of repurposed drugs for SARS-CoV-2 [14]

\section{The immunity battles}

The destruction of pulmonary cells initiates a local immune response involving macrophages and monocytes, which release an array of cytokines. This action also primes adaptive immunity by $\mathrm{T}$ and B cells. Mild cases of COVID-19 are primarily resolved at this stage. However, severe lung destruction is associated with a dysfunctional immune response. Pyroptosis of airway epithelial cells releases IL- $1 \beta$, a potential trigger for the eventual inflammatory response [16]. This wave of local inflammation is sensed by alveolar epithelial cells and alveolar macrophages and leads to the secretion of proinflammatory cytokines and chemokines like IL-6, interferon gamma, monocyte chemoattractant protein 1 and interferon gamma-induced protein 10 . This starts the pulmonary recruitment of monocytes and T lymphocytes into the infected site. Thus, the infiltration of lymphocytes into the respiratory airway manifests as T-cell lymphopenia, which is observed in the majority of COVID-19 patients [13,17]. Like SARS-CoV, the escape pathogen SARS-CoV-2 can sabotage the innate response by antagonism of the interferon response and disrupt the host protein translation process. This could potentially support viral replication and eventually manifest as pyroptosis-associated aberrant inflammation in the lungs $[13,18]$.

In most mild cases, recruited immune cells clear the respiratory airway, after which the immune response recedes. But a dysfunctional immune response is observed in severe cases, which triggers a massive cytokine storm that mediates extensive lung inflammation. The cytokine storm involves elevated blood plasma levels of macrophage inflammatory protein $1 \alpha$ (MIP1 $\alpha$ ), tumor necrosis factor (TNF), IL-2, IL7, IL-10, interferon gamma-induced protein 10, monocyte chemoattractant protein 1 and granulocyte-macrophage colony-stimulating factor. A high population of $\mathrm{CD} 14^{+} \mathrm{CD} 16^{+}$inflammatory monocytes, which also contribute to the cytokine storm, is also observed in severe cases. In addition, lymphocyte counts in peripheral blood are observed to significantly decrease [19]. Other observed consequences of T-cell lymphopenia and cytokine storm are hyaluronan formation and pulmonary edema. This contributes to severe breathlessness and vulnerability to secondary infections. The ripple effect of the cytokine storm brings about myocardial damage and multi-organ failure [3]. Transcriptomic analysis of three COVID-19 patients has revealed a dynamic early immune response [20]. After reaching the lowest point in respiratory function, a peak in most inflammatory and cytokine signaling gene expression, except expression in the IL-1 pathway, which preceded the decrease in respiratory function, was observed.

B-cell immune response is concomitantly observed 1 week after the onset of symptoms. The antibody response is observed against nucleocapsid and S protein by week 3 of SARS-CoV infection symptoms. However, some COVID-19 patients do not develop long-lasting antibodies $[13,21]$. Although many studies have made significant inroads, a clear understanding of the important host immune factors involved in the development of COVID-19 inflammation remains incomplete.

\section{COVID-19 and comorbidities}

The most distinctive comorbidities seen in fatalities or severe cases of COVID-19 are diabetes, cerebrovascular diseases, hypertension, coronary heart diseases and cancer. Since cells expressing ACE2 are normally found in the epithelial lining of the lungs, intestines, kidneys and blood vessels, patients with these comorbidities are more susceptible to SARS-CoV-2 [22]. Although efforts to develop targeted immune therapies and vaccines are underway, many health organizations are advocating the practice of yoga and Ayurveda and maintaining a healthy lifestyle to boost immunity [23,24]. Most therapies routinely prescribed for these comorbidities favor the gateway of SARS-CoV-2 (Table 1).

\section{Non-vaccine pharmacological swords against SARS-CoV-2}

Although some laboratories are involved in repurposing old antiviral drugs for use with the novel virus, some are involved in

Table 1

Current therapies recommended for COVID-19 comorbidities.

\begin{tabular}{|c|c|c|c|c|}
\hline Sl. no. & Comorbidity & Current therapy & Risks & Reference \\
\hline 1. & Diabetes (type 1 and 2) & ACE inhibitors and ARBs & Increased expression of $A C E 2$, poor prognosis & [25] \\
\hline 2 & Hypertension, cardiovascular diseases & $\begin{array}{l}\text { ACE inhibitors, ARBs, ibuprofen } \\
\text { and thiazolidinediones }\end{array}$ & Increased expression of $A C E 2$, poor prognosis & {$[26,27]$} \\
\hline 3 & Inflammatory lung diseases & $\begin{array}{l}\text { Macrolide or quinolone antibiotics } \\
\text { and steroids }\end{array}$ & Excess inflammation & [26] \\
\hline 4 & Cancer & Surgery or chemotherapy & $\begin{array}{l}\text { Increased severity due to delays in treatment } \\
\text { and low immunity }\end{array}$ & {$[28-30]$} \\
\hline 5 & Liver injury & $\begin{array}{l}\text { Macrolide or quinolone } \\
\text { antibiotics and steroids }\end{array}$ & Excess inflammatory response & [31] \\
\hline 6 & $\begin{array}{l}\text { Autoimmune diseases: } \\
\text { rheumatoid arthritis }\end{array}$ & $\begin{array}{l}\text { Corticosteroids, NSAIDs, } \\
\text { acetaminophen and TNF inhibitors }\end{array}$ & $\begin{array}{l}\text { Increased risk of secondary infection due } \\
\text { to immunosuppression }\end{array}$ & {$[32,33]$} \\
\hline
\end{tabular}

Sl. no., Serial number; ARBs, angiotensin receptor blockers; NSAIDs, non-steroidal anti-inflammatory drugs. 
designing targeted immune therapy. Remdesivir and lopinavir have shown a potential anti-viral effect and are being clinically investigated for safety and efficacy [34]. The efficacy of corticosteroid treatment for lung inflammation is also being questioned because of complications and delayed clearance of the infection [33]. Clinical trials to validate the efficacy of the anti-malarial drug hydroxychloroquine, which is also used to treat certain autoimmune diseases (lupus and rheumatoid arthritis); anti-cytokine therapies like IL-6 inhibitors and mesenchymal stromal cell-based therapies in COVID-19 patients are underway [35]. In such a scenario, where the production of an effective vaccine and anti-viral medicines is underway, convalescent plasma (CP) therapy and nanobodies have become exciting potential non-vaccine pharmacological tools for prevention [36].

\section{CP therapy: a pandemic savior?}

CP therapy is a typical adaptive immunotherapy that has been applied successfully to stem outbreaks of SARS, MERS, the H1N1 pandemic of 2009, poliomyelitis, measles and mumps [37,38,39]. However, the application of CP was not able to treat the Ebola virus. Since SARS, MERS and COVID-19 share some similarities in the immunopathogenesis of their etiological agent, $\mathrm{CP}$ is looked upon as a promising option for treating COVID-19 $[39,40]$. It has been reported by Walls et al. [41] that murine SARS-CoV S protein polyclonal antibodies could inhibit S protein-mediated SARS-CoV-2 entry, shedding light on the cross-neutralizing antibodies that target the $S$ epitope.

A study by Duan et al. [42] on the feasibility of CP transfusion in COVID-19 patients reported that a cohort of severely ill adult patients tolerated the therapy, and it significantly increased the titer of neutralizing antibodies, leading to reduction of clinical symptoms within 3 days and disappearance of viremia in a week. In a trial by China National Biotec Group Co Ltd (http://www.chictr.org.cn/showprojen. aspx?proj =49861), it was reported that 10 severely ill COVID-19 patients receiving $\mathrm{CP}$ therapy demonstrated significant improvement in oxygenation and pulmonary injury. Mechanistically, the hightiter-specific neutralizing antibodies could bring about complement activation and phagocytosis [42].

The key factors associated with CP therapy are neutralizing antibody titer, treatment time point and safety. Earlier studies on CP therapy for MERS-CoV demonstrated that the antibody titer should exceed 1:80 for full clearance. Hence, finding donors who have high titers is a prerequisite. It has been observed in SARS-CoV- and MERS$\mathrm{CoV}$-infected individuals that $\operatorname{IgG}$ titer reaches undetectable levels 3-4 months after recovery. Hence, it can be concluded that neutralizing antibodies represent a transient humoral immune response, and plasma from newly recovered patients should be more effective. The neutralizing antibody titer of recently recovered COVID-19 patients is above 1:640, which is higher than that seen in MERS patients [42].

SARS patients who were given $\mathrm{CP}$ before 14 days post onset of illness demonstrated a better outcome. Similarly, in the study by Duan et al. [42], patients who received CP transfusion before 14 days post onset of illness exhibited a spike in lymphocyte count and reduction in C-reactive protein, which is a marker of inflammation and cytokine storm. Patients who received CP after 14 days post onset of illness showed relatively less improvement, emphasizing the importance of an optimal transfusion time point. Stony Brook Hospital, New York, has initiated trials to test CP therapy for COVID-19 patients (https:// clinicaltrials.gov/ct2/show/NCT04344535). Recently, the US Food and Drug Administration approved access to CP for COVID-19 patients while emphasizing the use of regulatory measures and clinical trials before routinely administering this therapy [43]. It has been reported that worldwide use of this therapy has mushroomed very rapidly because of encouraging results in patients [44].

In a study by Joyner et al. [43], early implications of CP therapy in 500 individuals of diverse races and a median age of 62 years who had severe or life-threatening COVID-19 were studied. The researchers observed $<1 \%$ severe adverse events, including $0.3 \%$ mortality, within the first $4 \mathrm{~h}$ of transfusion. The 7-day mortality rate was $14.9 \%$, which could also be due to underlying multi-organ failure, sepsis and other significant comorbidities. The researchers discussed the possibility of developing transfusion-related acute lung injury (TRALI) and transfusion-associated circulatory overload (TACO), which are often difficult to identify, as associated pulmonary complications post therapy. TACO results in pulmonary edema and hypertension. TRALI is characterized by bilateral pulmonary edema with or without acute respiratory distress syndrome. In certain cases, it has been observed that an underlying lung injury or comorbidities in COVID-19 patients further complicate the diagnosis of TACO and TRALI, which could exacerbate transfusion-related risks in severe patients [43]. Transmission of pathogens is also a major risk associated with CP therapy [40].

To maintain the activity of antibodies and inactivate the virus in donated plasma, Duan et al. [42] applied Methylene Blue photochemistry, which is reported to be better than UV-C light. Earlier studies on CP therapy for Ebola have reported transfusion-related acute lung injury [42]. Antibody-dependent infection enhancement is an uncommon risk that can suppress innate anti-viral immunity and thus support intracellular growth of the virus. However, it may be assumed that because of the high titer of neutralizing antibodies, optimal time of infusion and transfusion volume, the risk of antibody-dependent infection can be avoided. Thus, the use of CP therapy may be beneficial for COVID-19 patients [45].

\section{Hyperimmune globulin treatment: a safe option?}

Nguyen et al. [46] define hyperimmune globulin as a product that is manufactured from the $\mathrm{CP}$ of thousands of donors with high antibody titers to a specific pathogen. It consists of an immune globulin fraction with well-defined properties. Plasmapheresis-derived plasma from recovered COVID-19 patients has been proposed to contain polyclonal hyperimmune globulin. This approach has already been explored for patients with SARS and severe influenza. It has been routinely used to treat patients infected with hepatitis $B$ and rabies, proving its precedence and sound therapeutic plausibility. Díez et al. [47] tested the hypothesized cross-reactivity using currently available intravenous immunoglobulin (IVIg) products Gamunex-C and Flebogamma DIF with SARS-CoV-2, SARS-CoV and MERS$\mathrm{CoV}$. The researchers observed noteworthy cross-reactivity to antigenic components, including the $\mathrm{S}$ protein. It has been anticipated that vaccine administration may not be able to elicit an immune response of high magnitude in acutely ill COVID-19 patients. Hyperimmune globulin treatment could treat the viral infection and reduce the cytokine storm in severely ill COVID-19 patients. To date, a number of mechanisms behind the anti-inflammatory effects of IVIg therapy have been discussed, including anti-complement mechanisms, anti-idiotypic neutralization of pathogenic auto-antibodies, regulation via Fc receptors, enhanced production of regulatory $T$ cells and inhibition of Th17 differentiation [47]. Hence, there have been suggestions for intravenous immunoglobulin therapy [48]. Although this needs to be confirmed through clinical trials, Takeda is advocating with regulatory agencies in the USA, Asia and Europe to expedite the use of anti-SARS-CoV-2 polyclonal hyperimmune globulin in highrisk patients with COVID-19 [49]. This could be a life-saving medicine for thousands of patients near death because of SARS-CoV-2.

\section{Therapeutic monoclonal antibodies against SARS-CoV-2: current scenario and challenges}

Many companies and academic laboratories across the world are striving to develop therapeutic antibodies against SARS-CoV-2 for the emergency prophylaxis and treatment of COVID-19. Regeneron, AstraZeneca, GlaxoSmithKline, AbCellera, Eli Lilly and Company, 
ImmunoPrecise, Mount Sinai Health System, Harbour BioMed and Vir Biotechnology, Inc, are some of the companies actively involved in developing functional therapeutic antibodies against SARS-COV-2 [50]. Regeneron's double mAbs combination (REGN-COV-2) and a therapeutic antibody (LY-CoV555) developed by Eli Lilly in collaboration with Abcellera are in Phase 3 and Phase 2 clinical trials, respectively. [https://clinicaltrials.gov/ct2/show/NCT04452318; https:// clinicaltrials.gov/ct2/show/NCT04427501].

Memory B cells of convalescent COVID-19 patient are the most used source for the identification of high-affinity neutralizing antibodies against SARS-CoV-2 (Figure 1). Another potential source is human trial testing for vaccines since an early immune response to the antigen is enough to release specific neutralizing antibodies with a high binding affinity [51]. S-RBD is an effective candidate for use in screening antibody-producing memory B cells for the development of therapeutics and diagnostics for SARS-CoV-2.

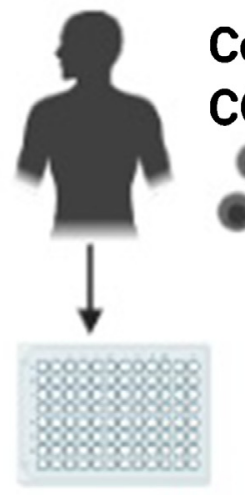

Convalescent COVID-19 patient

\section{PBMCs}

Isolation of RBD specific single memory $B$ cells

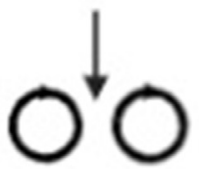

Amplification of $V_{H}$ and $V_{L}$ region and cloning to PCAGGS 1 plasmid

Transfection of HEK293T and MAb production 1

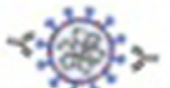

Neutralization of SARS-CoV-2

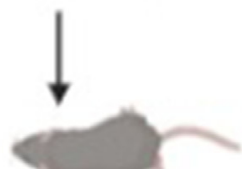

\section{In vivo protection of SARS-CoV-2- infected hACE2 mice model by mAbs $\mathrm{B} 38$ and $\mathrm{H} 4$}

Figure 1. SARS-CoV-2-neutralizing mAb production using single B-cell repertoire from recovered COVID-19 patient [53]. Created with BioRender.com. PBMCs, peripheral blood mononuclear cells. (Color version of figure is available online).
SARS-CoV-2 has a genome sequence that is $79.6 \%$ identical to that of SARS-CoV and 96\% identical to the bat coronavirus [52]. The RBD sequences of SARS-COV-2 share 73.8-74.9\% amino acid identity with SARS-CoV [53]. Both SARS-CoV and SARS-CoV-2 possess a conserved epitope in RBD that makes them cross-reactive [54]. S glycoprotein of SARS-CoV-2 has 10 times higher affinity to ACE2 than that seen with SARS-CoV. Much of this affinity is attributed to RBD's structural features, such as a more compacted ACE2 binding ridge and well-stabilized hotspots [55,56]. CR3022, a neutralizing antibody obtained from a convalescent SARS-CoV-infected patient, cross-reacted with SARS-CoV-2 $\mathrm{S}$ but could not cross-neutralize SARS-CoV-2 in vitro [54]. A cross-reactive $\mathrm{mAb}$ that neutralizes both SARS-CoV and SARSCoV-2 pseudoviruses and authentic viruses has been generated using transgenic H2L2 mice immunized with a combination of $S_{\text {ecto }}$ from different coronaviruses, such as human CoV-OC43, SARS-CoV and MERS-CoV (Figure 2), though the identified mAb exhibited higher binding affinity toward SARS-CoV S [8].

Past research on the development of therapeutic antibodies for SARS-CoV serves as a backbone for the development of feasible therapeutic antibodies for SARS-CoV-2. In 2004, Sui et al. [57] reported high-affinity humanized $\mathrm{mAbs}$ based on single-chain variable region fragment antibody 80R against the S1 domain of the $\mathrm{S}$ protein of SARS-CoV. These could effectively neutralize SARS-CoV and block the S1 protein binding with ACE2. However, 80R was not effective against the GD03 strain of SARS $\mathrm{CoV}$, which caused the second

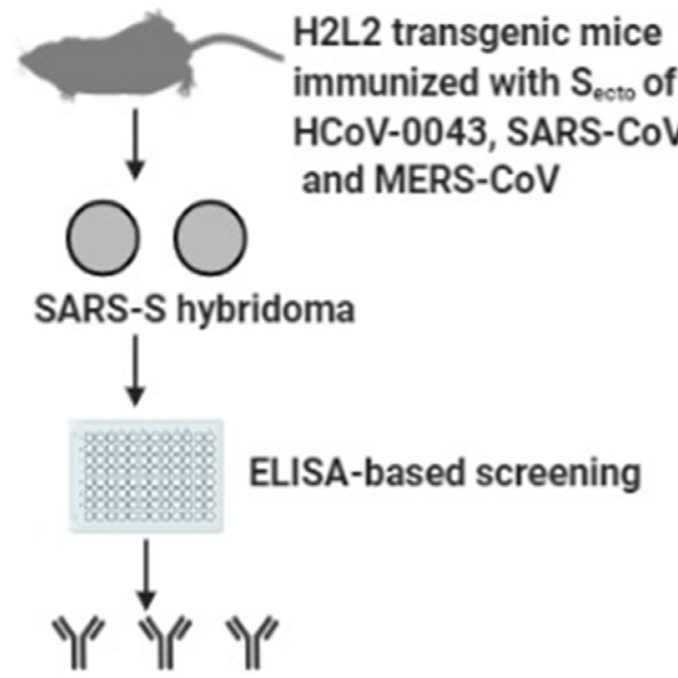

H2L2 mAbs

$\downarrow$ rDNA technology

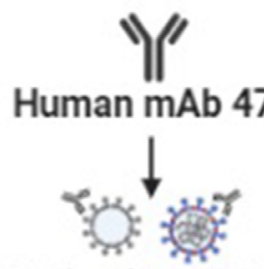

Neutralization of SARS-CoV S and SARS-CoV-2 $S$ pseudotyped viruses and authentic SARS-CoV and SARS-CoV-2 viruses

Figure 2. SARS-CoV-2-neutralizing mAb production using transgenic H2L2 mice [8] Created with BioRender.com. ELISA, enzyme-linked immunosorbent assay. (Color version of figure is available online). 
outbreak in 2003/2004. Zhu et al. [58] reported that humanized mAbs m396 and S230 successfully cross-react with the GD03 strain, Urbani and Tor2 isolates (first SARS outbreak) and SZ3 and SZ16 (pseudotyped viruses bearing spikes from palm civet), except bat-derived strains. Both antibodies block the SARS-CoV-ACE2 interaction by binding to the RBD of the SARS-CoV S protein. When 80R, m396 and S230 were tested against SARS-CoV-2 RBD, none of them showed significant binding regardless of the degree of structural homology between SARS-CoV S RBD and SARS-CoV-2 S RBD. Hence, the SARS$\mathrm{CoV}-2 \mathrm{~S}$ protein would be the ideal target for designing therapeutic mAbs against SARS-CoV-2 [55]. Yi et al. [59] provided some interesting insight into the critical amino acid differences between the SARS$\mathrm{CoV}$ and SARS-CoV-2 RBDs that result in their distinct immunogenicity and limit the cross-neutralizing activity of therapeutic antibodies.

Table 2 summarizes the neutralizing mAbs with therapeutic potential against SARS-CoV-2 reported thus far. Cao et al. [62] identified some potent SARS-CoV-2 mAbs based on the CDR3H structural similarity to SARS-CoV-neutralizing mAbs (m396 and 80R) from the large antigen-binding clonotype library produced by high-throughput single-cell $5^{\prime}$ mRNA and VDJ sequencing. The mAbs derived from memory B cells of a SARS survivor were cross-reactive to SARS-CoV and SARS-CoV-2 but not to OC43 and MERS-CoV [61]. Similarly, sarbecovirus cross-neutralizing antibodies were identified from memory B cells of a SARS survivor [64]. However, SARS-CoV-2-generated mAbs showed no cross-reactivity to SARS-CoV and MERS-CoV RBDs [63]. The mechanism of action for SARS-CoV-2 neutralizing mAbs is either by blocking the interaction between RBD and human ACE2 (hACE2) or by binding to the conserved epitope of S-RBD without competing for receptor binding. Neutralizing human mAbs exhibiting intense competition with the hACE receptor for RBD binding are quite potent against SARS-CoV-2 [62,63]. Yi et al. [59] reported that the RBD binding affinity and neutralizing ability of SARS-CoV-2-targeted mAbs generated by phage display were much weaker for SARS-CoV, which strengthens the species-specific nature of anti-RBD antibodies. A cocktail of $m A b s$ binding to the different epitopes on RBD will be more efficacious in neutralizing SARS-CoV-2 and preventing immune escape mutants than monotherapy with a candidate therapeutic mAb [53,62].

A major concern that should be addressed before implementation of antibody-based drug therapy or vaccination is antibody-dependent enhancement (ADE) of viral infection, in which virus-specific antibodies facilitate viral entry to immune cells by cross-linking the viral antibody or virus-activated complement complex to the cell surface Fc receptor or complement receptor, leading to viral replication and subsequently high viral load $[75,76]$. ADE has been reported for other coronaviruses [77-79]. Antibody-dependent infection with SARS-CoV-1 could allow the virus to widen the tropism by providing additional entry routes and contribute to pathogenicity. In ADE of SARS-CoV-1 infection, anti-S antibodies mediate viral entry to immune cells by cross-linking the virus-antibody complexes to the $\mathrm{Fc} \gamma$ receptor II, followed by internalization through a $\mathrm{pH}-$ and cysteine protease-independent pathway, which is distinct from the hACE2-mediated endosomal/lysosomal pathway [78]. Wan et al. [79] demonstrated cell surface IgG Fc receptor-mediated viral entry of MERS-CoV into Fc receptor-expressing cells through canonical viral receptor-dependent pathways.

It has been suggested that low concentration of neutralizing antibodies could cause ADE of SARS-CoV-2, as reported in the case of SARS-CoV-1 [80-82]. Specificity, concentration, affinity and isotope of the antibody are factors that influence the infection enhancing tendency of an antibody. Designer antibodies with higher affinity to RBD are less likely to induce ADE [81]. Engineering the Fc region of $\mathrm{mAbs}$ to abolish its affinity for the Fc $\gamma$ receptor is a feasible solution to mitigate the risk of ADE [80]. To abrogate the risk of ADE of SARS-CoV-2, LALA mutations were introduced to the FC region of $\mathrm{CB} 6$, a potent SARS-CoV-2-neutralizing antibody. CB6 (LALA) effectively reduced viral load and infection-related lung damage associated with SARSCoV-2 infection in rhesus macaques [68]. The possibility of ADE can also be minimized by maintaining a high concentration of circulating therapeutic antibodies, which is more easily achieved by improving the half-life of mAbs [83]. Lurie et al. [84] suggested that rigorous animal testing and pre-clinical trials should be conducted for therapeutic candidates against SARS-CoV-2, considering the adverse effects caused by ADE. The current uncertainty regarding the duration of functional protection by antibodies against SARS-CoV-2 RBD until the second wave of infection must be addressed to enhance the therapeutic efficacy of mAb products [85].

The ability of a virus to generate escape mutants because of immune pressure is a major challenge for successful vaccine and therapeutic antibody development. A pandemic scenario influenced by a highly diverse infected population also facilitates the generation of escape mutants [86]. RNA viruses such as SARS-CoV-2 exhibit a high mutation rate-up to a million times higher than the hostwhich drives viral evolution and adaptability [87,88]. High viral load of SARS-CoV-2 at the early stage of the disease might also contribute to anti-viral resistance [89]. Molecular modeling simulation studies of the antigen-antibody complex predict mutation of antigens that could disrupt the binding of antibodies and reduce the efficacy of mAb therapy [90]. It has been reported that escape mutants attenuate SARS-CoV infection. Formulation of more than one therapeutic antibody that binds to non-overlapping epitopes and/or parts of $S$ other than RBD has been proposed to neutralize resistant variants [91,92]. A cocktail of mAbs S227.14 and S230.15 has effectively cross-reacted with a broad range of human and zoonotic SARS-CoV isolates, including escape mutants [93]. The mAb combination targeting the N-terminal domain as well as RBD of SARS-CoV-2 could be effective against viral escape [69]. Single antibody treatment against SARSCoV-2 has induced escape mutants. Regeneron's mAbs cocktail, REGN10933 and REGN10987, each binds to the distinct epitopes of RBD prevented generation of escape mutants [94].

An effective passive immune therapy, along with stimulation of the endogenous humoral and cellular immune response, may provide durable protective immunity. Combining mAbs with immunostimulatory agents and altering antibody effector function through Fc-engineered $\mathrm{mAbs}$ are possible options to improve the long-lasting protective vaccine-like effects of mAbs [95]. Half-life and effector functions of S309, a mAb with neutralizing activity against SARSCoV-2, were improved with FC engineering [61].

The prospect of highly potent super-antibodies that can neutralize multiple viruses of a single family looks quite promising in terms of developing broadly active therapeutic agents against Coronaviridae viruses. Large-scale screening for a donor with broadly neutralizing serum and high-throughput B-cell isolation are critical steps in the discovery of super-antibodies [96]. Defining the immunodominant regions of the $\mathrm{S}$ protein of SARS-CoV-2 is critical, as it can reveal potential targets for immune response. Development of mAbs targeting conserved epitopes of RBD and the highly similar S2 subdomain is likely to give cross-protection across betacoronaviruses [71,97].

\section{Immunomodulation of cytokine storm syndrome using $\mathbf{m A b}$ therapy: need of the hour}

Targeted drug development is a time-consuming process. Repurposed drugs and therapeutic mAbs that modulate the immune response and improve the prognosis of COVID-19 patients should be considered at this critical time until a successful drug for viral clearance is on the market. An anti-IL6 mAb, tocilizumab, routinely used in the treatment of rheumatoid arthritis, has been found to mitigate cytokine storm syndrome and improve the outcome of COVID-19 patients. Apart from the anti-inflammatory action of tocilizumab, its role in halting coagulation activation greatly benefits COVID-19 patients with severe coagulopathy, which makes this therapy a more 
Table 2

Neutralizing antibodies with therapeutic potential against SARS-CoV-2.

\begin{tabular}{|c|c|c|c|c|c|}
\hline mAbs & Source & Mechanism of neutralization & IC50 & In vivo study & References \\
\hline 47D11 & Transgenic H2L2 mice & Binding to conserved epitope of spike RBD & $\begin{array}{l}0.061 \mu \mathrm{g} / \mathrm{mL} \text { (SARS-CoV-2 pseudotyped virus) } \\
0.57 \mu \mathrm{g} / \mathrm{mL} \text { (SARS-CoV-2 virus) }\end{array}$ & & [8] \\
\hline $\begin{array}{l}311 \mathrm{mAb}-31 \mathrm{~B} 5 \\
311 \mathrm{mAB}-32 \mathrm{D} 4\end{array}$ & $\begin{array}{l}\text { RBD-specific single B-cell repertoire from } \\
\text { recovered COVID-19 patient }\end{array}$ & Blocking binding of SARS-CoV-2 RBD to hACE2 & $\begin{array}{l}311 \mathrm{mAb}-31 \mathrm{~B} 5=0.0338 \mu \mathrm{g} / \mathrm{mL} \\
311 \mathrm{mAb}-32 \mathrm{D} 4=0.0698 \mu \mathrm{g} / \mathrm{mL} \text { (SARS-CoV-2 } \\
\text { pseudotyped virus) }\end{array}$ & $\mathrm{NI}$ & [60] \\
\hline $\begin{array}{l}\text { B38 } \\
\mathrm{H} 4\end{array}$ & $\begin{array}{l}\text { RBD-specific single B-cell repertoire from } \\
\text { COVID-19 patient }\end{array}$ & Blocking binding of SARS-CoV-2 RBD to hACE2 & $\begin{array}{l}\mathrm{B} 38=0.177 \mu \mathrm{g} / \mathrm{mL} \\
\mathrm{H} 4=0.896 \mu \mathrm{g} / \mathrm{mL} \\
\text { (SARS-CoV-2 virus) }\end{array}$ & $\begin{array}{l}\text { hACE2 transgenic mice } \\
\text { model }\end{array}$ & [53] \\
\hline HA001 & Phage display & Blocking binding of SARS-CoV-2 RBD to hACE2 & $0.016 \mu \mathrm{g} / \mathrm{mL}$ (SARS-CoV-2 pseudotyped virus) & $\mathrm{NI}$ & [59] \\
\hline S309 & $\begin{array}{l}\text { Memory B cells of person previously } \\
\text { infected with SARS-CoV }\end{array}$ & Binding to conserved epitope of spike RBD & $79 \mathrm{ng} / \mathrm{mL}$ (SARS-CoV-2 virus) & $\mathrm{NI}$ & [61] \\
\hline BD-368-2 & $\begin{array}{l}\text { High-throughput scRNA/VDJ sequencing } \\
\text { of COVID-19 convalescent patient's B } \\
\text { cells }\end{array}$ & Blocking binding of SARS-CoV-2 RBD to hACE2 & $\begin{array}{l}1.2 \mathrm{ng} / \mathrm{mL} \text { (SARS-CoV-2 pseudotyped virus) } \\
15 \mathrm{ng} / \mathrm{mL} \text { (SARS-CoV-2 virus) }\end{array}$ & $\begin{array}{l}\text { hACE2 transgenic mice } \\
\text { model }\end{array}$ & [62] \\
\hline $\begin{array}{l}\text { PC2-1F11 } \\
\text { P2B-2F6 } \\
\text { P2C-1A3 }\end{array}$ & $\begin{array}{l}\text { RBD-specific single B-cell repertoire from } \\
\text { COVID-19 patient }\end{array}$ & Blocking binding of SARS-CoV-2 RBD to hACE2 & $\begin{array}{l}\text { PC2-1F11 }=0.03 \mu \mathrm{g} / \mathrm{mL} \\
\text { P2B-2F6 }=0.05 \mu \mathrm{g} / \mathrm{mL} \\
\text { P2C-1A3 }=0.62 \mu \mathrm{g} / \mathrm{mL} \\
\text { (SARS-CoV-2 pseudotyped virus) } \\
\text { PC2-1F11 }=0.03 \mu \mathrm{g} / \mathrm{mL} \\
\text { P2B-2F6 }=0.41 \mu \mathrm{g} / \mathrm{mL} \\
\text { P2C-1A3 }=0.28 \mu \mathrm{g} / \mathrm{mL} \\
\text { (SARS-CoV-2 virus) }\end{array}$ & $\mathrm{NI}$ & [63] \\
\hline ADI-56046 & $\begin{array}{l}\text { RBD-specific single B-cell repertoire from } \\
\text { SARS-CoV survivor }\end{array}$ & $\begin{array}{l}\text { Binding to conserved epitopes in RBD and com- } \\
\text { peting with hACE2 binding }\end{array}$ & $\begin{array}{l}\approx 0.05 \mu \mathrm{g} / \mathrm{mL} \\
\text { (SARS-CoV-2 pseudotyped virus) } \\
<0.1 \mu \mathrm{g} / \mathrm{mL} \\
\text { (SARS-CoV-2 virus) }\end{array}$ & $\mathrm{NI}$ & [64] \\
\hline $\begin{array}{l}\text { COV2-2196, COV2-2130, } \\
\text { COV2-2381 }\end{array}$ & $\begin{array}{l}\text { SARS-CoV-2 S2P } \text { ecto }_{\text {or RBD- mFc-reac- }} \\
\text { tive single B cells from convalescent } \\
\text { COVID-19 patients }\end{array}$ & Blocking binding of SARS-CoV-2 RBD to hACE2 & $\begin{array}{l}\text { COV2-2196 }=0.7 \mathrm{ng} / \mathrm{mL} \\
\text { COV2-2130 }=1.6 \mathrm{ng} / \mathrm{mL} \\
\text { (SARS-CoV-2 } \mathrm{pseudotyped} \mathrm{virus)} \\
\text { COV2-2196 }=15 \mathrm{ng} / \mathrm{mL} \\
\text { COV2-2130 }=107 \mathrm{ng} / \mathrm{mL} \\
\text { (SARS-CoV-2 virus) }\end{array}$ & $\begin{array}{l}\text { Ad-hACE2 mouse model } \\
\text { and rhesus macaque } \\
\text { model }\end{array}$ & [65] \\
\hline CC12.1 & $\begin{array}{l}\text { SARS-CoV-2 RBD and S antigen-specific } \\
\text { single memory B cells from conva- } \\
\text { lescent COVID-19 patients }\end{array}$ & $\begin{array}{l}\text { Targeting RBD-A epitope by competing with } \\
\text { hACE2 and blocking its binding to SARS-CoV-2 } \\
\text { RBD }\end{array}$ & $\begin{array}{l}0.019 \mu \mathrm{g} / \mathrm{mL} \text { (SARS-CoV-2 pseudotyped virus) } \\
0.022 \mu \mathrm{g} / \mathrm{mL} \text { (SARS-CoV-2 virus) }\end{array}$ & Syrian hamster model & [66] \\
\hline $\begin{array}{l}\text { REGN10933 } \\
\text { REGN10987 }\end{array}$ & $\begin{array}{l}\text { Anti SARS-CoV-2 antibodies from immu- } \\
\text { nized VI mouse and RBD-specific single } \\
\text { B cells from convalescent COVID-19 } \\
\text { patients }\end{array}$ & Blocking binding of SARS-CoV-2 RBD to hACE2 & $\begin{array}{l}\text { REGN10933-42 pM } \\
\text { REGN10987- } 40 \mathrm{pM} \\
\text { (SARS-CoV-2 pseudotyped virus) } \\
\text { REGN10933-37 pM } \\
\text { REGN10987- } 42 \mathrm{pM} \\
\text { (SARS-CoV-2 pseudotyped virus) }\end{array}$ & $\begin{array}{l}\text { Rhesus macaque model } \\
\text { and golden hamster } \\
\text { model }\end{array}$ & [67] \\
\hline CB6 & $\begin{array}{l}\text { RBD-specific memory B cells from conva- } \\
\text { lescing COVID-19 patients }\end{array}$ & Blocking binding of SARS-CoV-2 RBD to hACE2 & $\begin{array}{l}\mathrm{ND}_{50}-0.036 \mu \mathrm{g} / \mathrm{mL} \text { (SARS-CoV-2 pseudotyped } \\
\text { virus) } \\
\mathrm{ND}_{50}-0.036 \mu \mathrm{g} / \mathrm{mL} \text { (SARS-CoV-2 virus) }\end{array}$ & Rhesus macaque model & [68] \\
\hline
\end{tabular}




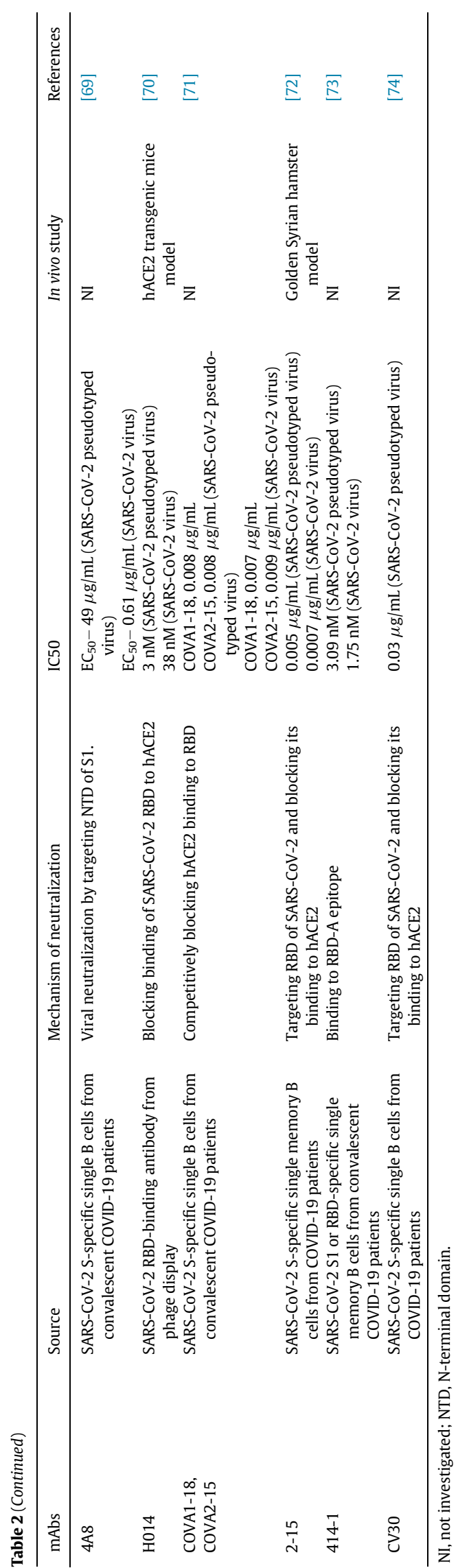

effective treatment than general anti-inflammatory interventions [98]. Tocilizumab has been recommended for critical COVID-19 patients in China and India who have significantly high levels of IL-6 $[99,100]$. A clinical trial is underway to investigate the use of $\mathrm{mAbs}$ targeting GM-CSF for the intervention of inflammatory cytokine storm caused by SARS-CoV-2 (https://clinicaltrials.gov/ct2/show/ NCT04341116). Moreover, since TNF is a major player in the inflammatory response, targeting it with an anti-TNF antibody is a feasible strategy to reduce COVID-19-induced lung inflammation and related inflammatory markers [101]. In addition, administration of anti-C5a $\mathrm{mAbs}$ is presumed to have a role in the mitigation of COVID-19-associated lung injury [50].

\section{Nanobodies as a promising therapeutic agent against SARS-COV-2}

Llama-based nanobodies have been implicated in designing antiviral therapy against HIV, rotavirus and respiratory syncytial virus [102-104]. Nanobodies are fully functional single-domain antibodies obtained from the camelid family, comprising a single variable domain (VHH) instead of two variable domains, as in the case of human antibodies. Their small size $(\approx 14 \mathrm{kDa})$, good solubility and excellent stability, along with high antigen specificity, make them a superior candidate over conventional antibodies [105]. Nanobodies can be easily produced in yeast or a bacterial host by recombinant technology [106]. The potency of nanobodies can be enhanced by engineering monovalent VHH into multivalent VHH [102]. SARS-CoV S-directed VHH (SARS VHH-72) generated in immunized llama cross-react with the SARSCoV-2 S protein. Though the binding of SARS VHH-72 to SARS-CoV-2 RBD-SD1 is weaker, an engineered bivalent VHH Fc construct results in successful neutralization of SARS-CoV-2 pseudoviruses in vitro. Upon binding of $\mathrm{VHH}, \mathrm{RBD}$ undergoes a dynamic conformational change that prevents its binding to the host cell receptor. Antibody panning with SARS-CoV-2 S can yield VHH with more stable binding and affinity toward SARS-CoV-2 RBD [107]. Further investigation is warranted to determine the feasibility of nanobodies as anti-viral therapy. Two nanobodies (H11-D4 and H11-H4) that neutralize SARS-CoV-2 by blocking the RBD and hACE2 interaction were identified by Huo et al. [108]. Fully human single-domain antibodies against SARS-CoV-2 were constructed using the human single-domain antibody phage display library [109]. An engineered trivalent nanobody with remarkable potency and stability was made into an inhalable formulation that could give protection against SARS-CoV-2, though effectiveness is yet to be proven by clinical trials [110].

\section{Cellular immune therapy for SARS-CoV-2 infection: a field worth exploring?}

T cells play an important role in the viral clearance of SARS-CoV. Reduction in viral titer and improvement in survival were observed in SARS-CoV-infected SCID and BALB/c mice on adoptive transfer of in vitro-generated SARS-CoV-specific effector CD4+ and CD8+ T cells [111]. Channappanavar et al. [112] suggested that boosting virus-specific memory T-cell responses of the host may be a good therapeutic strategy against SARS-CoV infection. A drastic reduction in total $\mathrm{T}$ cells was reported in COVID-19 patients [113]. Sekine et al. [114] demonstrated T-cell phenotypes associated with acute and convalescent COVID-19 patients [114]. Strong memory T-cell responses were elicited in mild and asymptomatic COVID-19 patients, implicating the potential role of $\mathrm{T}$ cells in immunity against SARS-CoV-2. A clinical trial is ongoing for the treatment of severe COVID-19 patients using clinical-grade SARS-CoV-2-specific T cells from the blood of convalescent donors (https://www.clinicaltrials.gov/ct2/show/ NCT04351659). However, serious concerns, such as donor matching and induction of cytokine storm, should be addressed before the implication of adoptively transferred T cells for viral infection [115]. 


\section{Discussion}

Unlike a newly emerged virion, the distance to successful immunotherapy against SARS-CoV-2 is not long, as there have been some advances in the therapeutic management of infections caused by previously emerged coronaviruses (SARS-CoV and MERS-CoV). CP therapy and the more refined IVIg approach are the currently available effective treatment options for SARS-CoV-2 infection. Human mAbs that prevent viral entry into the host by inhibiting viral attachment to the receptor show efficient SARS-CoV-2 neutralization in vitro and in vivo. The protective ability of a developed therapeutic antibody can be challenged by viral mutation under selection pressure. The use of combination mAbs has been a promising approach to overcoming the emergence of escape mutants. Treatment benefits of these promising candidates can only be assessed through randomized controlled trials. Further, if therapeutic candidates are proven safe and efficacious in the treatment of SARS$\mathrm{CoV}-2$ infection, policy makers should be well equipped for the mass production and distribution of anti-viral therapeutics in response to the pandemic threat. Apart from the lack of a successful therapy, the high mortality rate associated with COVID-19 has been attributed to the paucity of understanding regarding the immunopathology of SARS-CoV-2 infection and underlying comorbidities. Triggering immunomodulation using mAbs targeting inflammatory cytokines can be used to treat the life-threatening cytokine storm syndrome. Though developing therapeutic antibodies targeting SARS-CoV-2 is the primary need of the current scenario, designing super-antibodies that neutralize multiple coronaviruses can make the world ready to tackle a future coronavirus outbreak.

\section{Funding}

No funding was received.

\section{Declaration of Competing Interest}

The authors have no commercial, proprietary or financial interest in the products or companies described in this article.

\section{Author Contributions}

Conception and design of the study: KVS and SK. Acquisition of data: KVS and SK. Analysis and interpretation of data: KVS and SK. Drafting or revising the manuscript: KVS and SK. Both authors have approved the final article.

\section{Acknowledgments}

KVS would like to acknowledge Dr D.S. Kothari Post-Doctoral Fellowship scheme of University Grant Commission, New Delhi, India, for the fellowship. SK would like to acknowledge University Grant Commission, New Delhi, India, for the senior research fellowship.

\section{References}

[1] World Health Organization. Coronavirus Disease (COVID-19) Dashboard. Updated August 21, 2020. https://covid19.who.int/. Accessed June 18, 2020.

[2] Wölfel R, Corman VM, Guggemos W, Seilmaier M, Zange S, Muller MA, et al. Virological assessment of hospitalized patients with COVID-2019. Nature 2020;581:465-9.

[3] Shi Y, Wang Y, Shao C, Huang J, Gan J, Huang X, et al. COVID-19 infection: the perspectives on immune responses. Cell Death Differ 2020:27:1451-4.

[4] Le Breton C, Besset S, Freita-Ramos S, Amouretti M, Billiet PA, Dao M, et al. Extracorporeal membrane oxygenation for refractory COVID-19 acute respiratory distress syndrome. J Crit Care 2020;60:10-2.

[5] Stebbing J, Phelan A, Griffin I, Tucker C, Oechsle O, Smith D, et al. COVID-19: combining antiviral and anti-inflammatory treatments. The Lancet Infectious Diseases 2020;20(4):400-2

[6] RECOVERY Collaborative Group. Dexamethasone in hospitalized patients with Covid-19-preliminary report. N Engl J Med 2020:NEJMoa2021436.
[7] Wu F, Zhao S, Yu B, Chen YM, Wang W, Song ZH, et al. A new coronavirus associated with human respiratory disease in China. Nature 2020:579:265-9.

[8] Wang C, Li W, Drabek D, Nisreen MAO, Haperen RV, Osterhaus ADME, et al. A human monoclonal antibody blocking SARS-CoV-2 infection. Nat Commun $2020 ; 11: 2251$.

9] Zhang $\mathrm{H}$, Penninger JM, Li Y, Zhong N, Slutsky AS, Angiotensin-converting enzyme 2 (ACE2) as a SARS-CoV-2 receptor: molecular mechanisms and potential therapeutic target. Intensive Care Med 2020;46:586-90.

[10] Patel VB, Clarke N, Wang Z, Fan D, Parajuli N, Basu R, et al. Angiotensin II induced proteolytic cleavage of myocardial ACE2 is mediated by TACE/ADAM-17: a positive feedback mechanism in the RAS. J Mol Cell Cardiol 2014;66:167-76.

[11] Gheblawi M, Wang K, Viveiros A, Nguyen Q Zhong JC, Turner AJ, et al. Angiotensin-converting enzyme 2: SARS-CoV-2 receptor and regulator of the reninangiotensin system: celebrating the 20th anniversary of the discovery of ACE2. Circ Res 2020;126(10):1456-74.

[12] Zhu N, Wang W, Liu Z, et al. Morphogenesis and cytopathic effect of SARS-CoV-2 infection in human airway epithelial cells. Nat Commun 2020;11:3910.

[13] Tay MZ, Poh CM, Rénia L, MacAry PA, Ng LFP. The trinity of COVID-19: immunity, inflammation and intervention. Nat Rev Immunol 2020;20:363-74.

[14] Epidemiology Working Group for NCIP Epidemic Response. The epidemiological characteristics of an outbreak of 2019 novel coronavirus diseases (COVID-19) in China. Chin. J. Epidemiol. 2020;41:145-51.

[15] Taneja V. Sex hormones determine immune response. Front Immunol 2018;9:1931.

[16] Cao X. COVID-19: immunopathology and its implications for therapy. Nat Rev Immunol 2020;20:269-70.

[17] Thevarajan I, Nguyen THO, Koutsakos M, Druce J, Caly L, van de Sandt CE, et al. Breadth of concomitant immune responses prior to patient recovery: a case report of non-severe COVID-19. Nat Med 2020;26:453-5.

[18] Iwasaki A, Yang Y. The potential danger of suboptimal antibody responses in COVID-19. Nat Rev Immunol 2020;20(6):339-41.

[19] Ahmadpoor P, Rostaing L. Why the immune system fails to mount an adaptive immune response to a Covid-19 infection. Transpl Int 2020;33(7):824-5.

[20] Ong EZ, Chan YF, Leong WY, Lee MN, Kalimuddin S, Mohideen SMH, et al. A dynamic immune response shapes COVID-19 progression. Cell Host Microbe 2020;27. 79-882.e2

[21] Totura AL, Baric RS. SARS coronavirus pathogenesis: host innate immune responses and viral antagonism of interferon. Curr Opin Virol 2012:2:2264-75.

[22] Wang T, Du Z, Zhu F, Cao Z, An Y, Gao Y, et al. Comorbidities and multi-organ injuries in the treatment of COVID-19. Lancet 2020;395:e52.

[23] Galea S, Merchant RM, Lurie N. The mental health consequences of COVID-19 and physical distancing: the need for prevention and early intervention. JAMA Intern Med 2020;180(6). 917-818.

[24] Rajkumar RP. Ayurveda and COVID-19: where psychoneuroimmunology and the meaning response meet. Brain Behav Immun 2020;87:8-9.

[25] Fang L, Karakiulakis G, Roth M. Are patients with hypertension and diabetes mellitus at increased risk for COVID-19 infection? The Lancet Respir Med 2020;8:E21.

[26] Zheng Y, Ma Y, Zhang J, Xie X. COVID-19 and the cardiovascular system. Nat Rev Cardiol 2020;17:259-60

[27] AlGhatrif M, Cingolani O, Lakatta EG. The dilemma of coronavirus disease 2019, aging, and cardiovascular disease: insights from cardiovascular aging science. JAMA cardiol 2020;5(7):747-8

[28] Kutikov A, Weinberg DS, Edelman MJ, Horwitz EM, Uzzo RG, et al. A war on two fronts: cancer care in the time of COVID-19. Ann Intern Med 2020;M20:113.

[29] Wang H, Zhang L. Risk of COVID-19 for patients with cancer. Lancet Oncol 2020;21:e181

[30] Hanna TP, Evans GA, Booth CM. Cancer, COVID-19 and the precautionary principle: prioritizing treatment during a global pandemic. Nat Rev Clin Oncol 2020;17:268-70.

[31] Xu L, Liu J, Lu M, Yang D, Zheng X. Liver injury during highly pathogenic human coronavirus infections. Liver Int 2020;40:998-1004.

[32] Favalli EG, Ingegnoli F, De Lucia O, Cincinelli G, Cimaz R, Caporali R. COVID-19 infection and rheumatoid arthritis: faraway, so close!. Autoimmun Rev 2020;20:102523.

[33] Sarzi-Puttini P, Marotto D, Antivalle M, Salaffi F, Atzeni F, Maconi G. How to handle patients with autoimmune rheumatic and inflammatory bowel diseases in the COVID-19 era: an expert opinion. Autoimmun Rev 2020;19(7):102574

[34] Dong L, Hu S, Gao J. Discovering drugs to treat coronavirus disease 2019 (COVID19). Drug Discov Ther 2020;14:58-60.

[35] Khoury M, Rocco PR, Phinney DG, Krampera M, Martin I, Viswanathan S, et al Cell-based therapies for COVID-19: proper clinical investigations are essentia [Article in Press]. Cytotherapy 2020.

[36] Liu C, Zhou Q Li Y, Garner LV, et al. Research and development on therapeutic agents and vaccines for COVID-19 and related human coronavirus diseases. ACS Cent. Sci 2020;6:315-31.

[37] Stockman LJ, Bellamy R, Garner P. SARS: systematic review of treatment effects. PLoS Med 2006;3(9):e343.

[38] Zhou B, Zhong N, Guan Y. Treatment with convalescent plasma for influenza A (H5N1) infection. N Engl J Med 2007;357:1450-1.

[39] Cancio M, Ciccocioppo R, Rocco P, Levine B, Bronte V, Bollard CM, et al. Emerging Trends in COVID-19 Treatment: Learning from Inflammatory Conditions Associated with Cellular Therapies. Cytotherapy 2020;22(9):474-81.

[40] Chen L, Xiong J, Bao L, Shi Y. Convalescent plasma as a potential therapy for COVID-19. Lancet Infect Dis 2020;20:398-400.

[41] Walls AC, Park YJ, Tortorici MA, et al. Structure, function, and antigenicity of the SARS-CoV-2 spike glycoprotein. Cell 2020;181. 281-292.e6. 
[42] Duan K, Liu B, Li C, Zhang H, Yu T, Qu J, Zhou M, et al. Effectiveness of convalescent plasma therapy in severe COVID-19 patients. Proc Natl Acad Sci U S A 2020;117(17):9490-6.

[43] Joyner M, Wright RS, Fairweather D, Senefeld J, Bruno K, Klassen S, et al. Early Safety Indicators of COVID-19 Convalescent Plasma in 5,000 Patients. J Clin Invest 2020:130(9):4791-7.

[44] Rubin R. Testing an Old Therapy Against a New Disease: Convalescent Plasma for COVID-19. JAMA 2020;323(21):2114-7

[45] Shen C, Wang Z, Zhao F, Yang Y, Li J, Yuan J, et al. Treatment of 5 critically ill patients with COVID-19 with convalescent plasma. JAMA 2020;323:1582-9.

[46] Nguyen AA, Habiballah SB, Platt CD, Geha RS, Chou JS, McDonald DR. 2020 Immunoglobulins in the treatment of COVID-19 infection: proceed with caution!. Clin Immunol 2020;216:108459.

[47] Díez JM, Romero C, Gajardo R. Currently available intravenous immunoglobulin contains antibodies reacting against severe acute respiratory syndrome coronavirus 2 antigens. Immunotherapy 2020;12(8):571-6.

[48] de Alwis R, Chen S, Gan ES, Ooi EE. Impact of immune enhancement on Covid-19 polyclonal hyperimmune globulin therapy and vaccine development. EBioMedicine 2020;16:102768.

[49] Takeda. Takeda Initiates Development of a Plasma-Derived Therapy for COVID-19. https://www.takeda.com/newsroom/newsreleases/2020/takeda-initiates-development-of-a-plasma-derived-therapy-for-covid-19/. Accessed 11 June 2020.

[50] Tu YF, Chien CS, Yarmishyn AA, Lin YY, Luo YH, Li YT, et al. A Review of SARS CoV-2 and the Ongoing Clinical Trials. Int J Mol Sci 2020;21(7):2657.

[51] Rijal P, Elias SC, Machando SR, Xiao J, Schimanzki L, O’Dowd V, et al. Therapeutic Monoclonal Antibodies for Ebola Virus Infection Derived from Vaccinated Humans. Cell Rep 2019;27:172-86

[52] Zhou P, Yang X, Wang XG, Hu B, Zhang L, et al. A pneumonia outbreak associated with a new coronavirus of probable bat origin. Nature 2020:579:270-3.

[53] Wu Y, Wang F, Shen C, Peng W, Li D, Zhao C, et al. A noncompeting pair of human neutralizing antibodies block COVID-19 virus binding to its receptor ACE2. Science 2020;368(6496):1274-8

[54] Yuan M, Wu NC, Zhu X, Lee CCD, So RTY, Lv H, et al. A highly conserved cryptic epitope in the receptor binding domains of SARS-CoV-2 and SARS-CoV. Science 2020: 368 (6491)630-633.

[55] Wrapp D, Wang N, Corbett KS, Goldsmith JA, Hsieh CL, Abiona O, et al. Cryo-EM structure of the 2019-nCoV spike in the prefusion conformation. Science 2020;367(6483):1260-3.

[56] Shang J, Ye G, Shi K, Wan Y, Luo C, Aihara H, et al. Structural basis of receptor recognition by SARS-CoV-2. Nature 2020;581:221-4.

[57] Sui J, Li W, Murakami A, Tamin A, Matthews LJ, Wong SK, et al. Potent neutralization of severe acute respiratory syndrome (SARS) coronavirus by a human mAb to S1 protein that blocks receptor association. Proc Natl Acad Sci U S A 2004;101 (8):2536-41

[58] Zhu Z, Chakraborti S, He Y, Roberts A, et al. Potent cross-reactive neutralization of SARS coronavirus isolates by human monoclonal antibodies. Proc Natl Acad Sci U S A 2007:104. 12123-1212.

[59] Yi C, Sun X, Ye J, Ding L, Liu M, Yang Z, et al. Key residues of the receptor binding motif in the spike protein of SARS-CoV-2 that interact with ACE2 and neutralizing antibodies. Cell Mol Immunol 2020;17:621-30.

[60] Chen X, Li R, Pan Z, Qian C, Yang Y, You R, et al. Human monoclonal antibodies block the binding of SARS-CoV-2 spike protein to angiotensin converting enzyme 2 receptor. Cell Mol Immunol 2020;17:647-9.

[61] Pinto D, Park Y, Beltramello M, Walls AC, Tortorici A, Bianchi S, et al. Cross-neutralization of SARS-CoV-2 by a human monoclonal SARS-CoV antibody. Nature 2020;583:290-5

[62] Cao Y, Su B, Guo X, Sun W, Deng Y, Bao L, et al. Potent Neutralizing Antibodies against SARS-CoV-2 Identified by High-Throughput Single-Cell Sequencing of Convalescent Patients' B Cells. Cell 2020;182. 73-84.e16.

[63] Ju B, Zhang Q, Ge J, Wang R, Sun J, Ge X, Yu J, et al. Human neutralizing antibodies elicited by SARS-CoV-2 infection. Nature 2020:584:115-9.

[64] Wec AZ, Wrapp D, Herbert AS, Maurer DP, Haselwanter D, Sakharkar M, et al. Broad neutralization of SARS-related viruses by human monoclonal antibodies. Science 2020:369(6504):731-6

[65] Zost SJ, Gilchuk P, Case JB, Binshtein E, Chen RE, NKolola JP, et al. Potently neutralizing and protective human antibodies against SARS-CoV-2. Nature 2020;584:443-9.

[66] Rogers TF, Zhao F, Huang D, Beutler N, Burns A, He WT, et al. Isolation of potent SARS-CoV-2 neutralizing antibodies and protection from disease in a small animal model. Science2020; 369(6506): 953-963.

[67] Hansen J, Baum A, Pascal KE, Russo V, Giordano S, Wloga E, et al. Studies in humanized mice and convalescent humans yield a SARS-CoV-2 antibody cocktail. Science 2020;369(6506):1010-4. eabd0827.

[68] Shi R, Shan C, Duan X, Chen Z, Liu P, Song J, et al. A human neutralizing antibody targets the receptor-binding site of SARS-CoV-2. Nature 2020;584:120-4.

[69] Chi X, Yan R, Zhang J, Zhang G, Zhang Y, Hao M, et al. A neutralizing human antibody binds to the N-terminal domain of the Spike protein of SARS-CoV-2. Science 2020:369(6504):650-5.

[70] Lv Z, Deng YQ, Ye Q Cao L, Sun CY, Fan C, et al. Structural basis for neutralization of SARS-CoV-2 and SARS-CoV by a potent therapeutic antibody. Science 2020;369(6510):1505-9.

[71] Brouwer PJM, Caniels TG, van der Straten K, Snitselaar JL, Aldon Y, Bangaru S, et al. Potent neutralizing antibodies from COVID-19 patients define multiple targets of vulnerability. Science 2020;369(6504):643-50.
[72] Liu L, Wang P, Nair MS, Yu J, Rapp M, Wang Q, Luo Y, et al. Potent neutralizing antibodies against multiple epitopes on SARS-CoV-2 spike. Nature 2020:584:450-6.

[73] Wan J, Xing S, Ding L, Wang Y, Gu C, Wu Y, et al. Human IgG neutralizing monoclonal antibodies block SARS-CoV-2 infection. Cell Rep 2020;32 (3):107918.

[74] Seydoux E, Homad LJ, MacCamy AJ, Parks KR, Hurlburt NK, Jennewein MF, et al. Analysis of a SARS-CoV-2-Infected Individual Reveals Development of Potent Neutralizing Antibodies with Limited Somatic Mutation. Immunity 2020;53(1). 98-105.e5.

[75] Takada A, Kawaoka Y. Antibody-dependent enhancement of viral infection: molecular mechanisms and in vivo implications. Rev Med Virol 2003;13(6):387-98.

[76] Beck Z, Prohászka Z, Füst G. Traitors of the immune system-enhancing antibodies in HIV infection: their possible implication in HIV vaccine development. Vaccine 2008;26(24):3078-85

[77] Hohdatsu T, Yamada M, Tominaga R, Makino K, Kida K, Koyama H. Antibodydependent enhancement of feline infectious peritonitis virus infection in feline alveolar macrophages and human monocyte cell line U937 by serum of cats experimentally or naturally infected with feline coronavirus. J Vet Med Sci 1998:60(1):49-55

[78] Jaume M, Yip MS, Cheung CY, Leung HL, Li PH, Kein F, et al. Anti-severe acute respiratory syndrome coronavirus spike antibodies trigger infection of human immune cells via a $\mathrm{pH}-$ and cysteine protease-independent $\mathrm{Fc} \gamma \mathrm{R}$ pathway. J Virol 2011:85(20):10582-97.

[79] Wan Y, Shang J, Sun S, Wanbo T, Chen J, Geng Q, et al. Molecular Mechanism for Antibody-Dependent Enhancement of Coronavirus Entry. J Virol 2020;94: e02015-9.

[80] Eroshenko N, Gill T, Keaveney MK, Church GM, Trevajo JM, Rajaniemi H. Implications of antibody-dependent enhancement of infection for SARS-CoV-2 countermeasures. Nat Biotechnol 2020;38:789-91.

[81] Iwasaki A, Yang Y. The potential danger of suboptimal antibody responses in COVID-19. Nat Rev Immunol 2020;20(6):339-41

[82] Wang SF, Tseng SP, Yen CH, Yen CH, Yang JY, Tsao CH, et al. Antibody-dependent SARS coronavirus infection is mediated by antibodies against spike proteins. Biochem Biophys Res Commun 2014;451(2):208-14

[83] Chan KR, Ong EZ, Mok DZ, Ooi EE. Fc receptors and their influence on efficacy of therapeutic antibodies for treatment of viral diseases. Expert Rev Anti Infect Ther 2015:13(11):1351-60.

[84] Lurie N, Saville M, Hatchett R, Halton J. Developing Covid-19 Vaccines at Pandemic Speed. J N Engl J Med 2020;382:1969-73.

[85] Altmann DM, Douek DC, Boyton R. What policy makers need to know about COVID-19 protective immunity. Lancet 2020;395:1527-9.

[86] Purdy MA. Hepatitis B virus S gene escape mutants. Asian J Transfus Sci 2007; 1:62-70.

[87] Pachetti M, Marini B, Benedetti F, Giudici F, Mauro E, Storici P, et al. Emerging SARS-CoV-2 mutation hot spots include a novel RNA-dependent-RNA polymerase variant. J Transl Med 2020;18:179.

[88] Duffy S. Why are RNA virus mutation rates so damn high? PLoS Biol 2008;16(8): e3000003.

[89] Chen Y, Li L. SARS-CoV-2: virus dynamics and host response. Lancet 2020;20: 515-6.

[90] Patel JS, Quates CJ, Johnson EL, Ytreberg FM. Expanding the watch list for potential Ebola virus antibody escape mutations. PLoS One 2019;14(3):e0211093.

[91] ter Meulen J, Van den Brink EN, Poon LL, Marissen WE, Leung CSW, Cox F, et al. Human monoclonal antibody combination against SARS coronavirus: synergy and coverage of escape mutants. PLoS Med 2006;3:e237.

[92] Wang L, Shi W, Chappell JD, Joyce G, Zhang Y, Kanekiyo M, et al. Importance of Neutralizing Monoclonal Antibodies Targeting Multiple Antigenic Sites on the Middle East Respiratory Syndrome Coronavirus Spike Glycoprotein To Avoid Neutralization Escape. J Virol 2018;92(10):e02002-17.

[93] Rockx B, Donaldson E, Frieman M, Sheahan T, Corti D, et al. Escape from human monoclonal antibody neutralization affects in vitro and in vivo fitness of severe acute respiratory syndrome coronavirus. J Infect Dis 2010;201(6):946-955.

[94] Baum A, Fulton BO, Wloga E, Copin R, Pascal KE, Russo V, et al. Antibody Cocktail to SARS-Cov-2 Spike Protein Prevents Rapid Mutational Escape Seen with Individual Antibodies. Science 2020;369(6506):1014-8.

[95] Pelegrin M, Naranjo-Gomez M, Piechaczyk M. Antiviral Monoclonal Antibodies: Can They Be More Than Simple Neutralizing Agents? Trends Microbiol $2015 \cdot 23: 10$

[96] Walker L, Burton D. Passive immunotherapy of viral infections: 'super-antibodies' enter the fray. Nat Rev Immunol 2018;18:297-308.

[97] Grifoni A, Sidney J, Zhang Y, Scheuermann RH, Peter B, Sette A. A Sequence Homology and Bioinformatic Approach Can Predict Candidate Targets for Immune Responses to SARS-CoV-2. Cell Host Microbe 2020;27(4). 671-680.e2.

[98] Levi M. Tocilizumab for severe COVID-19: a promising intervention affecting inflammation and coagulation. Eur J Intern Med 2020;76:21-22.

[99] National Health Commission \& National Administration of Traditional Chinese Medicine. Diagnosis and treatment protocol for novel coronavirus pneumonia (Trial Version 7). Chin Med J 2020;133(9):1087-95

[100] Government of India. Clinical Management Protocol, Accessed June 162020 https://www.mohfw.gov.in/pdf/ClinicalManagementProtocolforCOVID19.pdf

[101] Feldmann M, Maini RM, Woody JN, Holgate ST, Winter G, Rowland M, et al. Trials of anti-tumour necrosis factor therapy for covid-19 are urgently needed. Lancet 2020;395:1407-9

[102] Forsman A, Beirnaert E, Aasa-Chapman MM, Hoorelbeke B, Hijazi K, Koh W, et al. Llama antibody fragments with cross-subtype human immunodeficiency virus 
type 1 (HIV-1)-neutralizing properties and high affinity for HIV-1 gp120. J Virol 2008;82. 12069-12081.

[103] Garaicoechea L, Olichon A, Marcoppido G, Wigdorovitz A, Mozgovoj M, Saif L, et al. Llama-derived single-chain antibody fragments directed to rotavirus VP6 protein possess broad neutralizing activity in vitro and confer protection against diarrhea in mice. J Virol 2008;82:9753-9764.

[104] Detalle L, Stohr T, Palomo C, Piedra PA, Gilbert BE, Vicente Mas, Millar A, et al. Generation and Characterization of ALX-0171, a Potent Novel Therapeutic Nanobody for the Treatment of Respiratory Syncytial Virus Infection. Antimicrob Agents Chemother 2015;60:6-13.

[105] Dumoulin M, Conrath K, Van Meirhaeghe A, Meersman F. Single-domain antibody fragments with high conformational stability. Protein Sci 2002;11:500-515.

[106] Wolfson W. Ablynx Makes Nanobodies from Llama Bodies. Chem Biol 2006;13:1243-4

[107] Wrapp D, De Vilega D, Corbett KS, Torres GM, Wang N, Breedam WV, et al. Structural Basis for Potent Neutralization of Betacoronaviruses by Single-Domain Camelid Antibodies. Cell 2020;181(5). 1004-1015.e15.

[108] Huo J, Le Bas A, Ruza RR, Duyvesteyn HME, Mikolajek H, Malinauskas T, et al. Neutralizing nanobodies bind SARS-CoV-2 spike RBD and block interaction with ACE2. Nat Struct Mol Biol 2020;27:846-54.
[109] Wu Y, Li C, Xia S, Tian X, Kong Y, Wang Z, et al. Identification of Human SingleDomain Antibodies against SARS-CoV-2. Cell Host Microbe 2020;27(6). 891-898.e5.

[110] University of California San Francisco. 'AeroNabs' Promise Powerful, Inhalable Protection Against COVID-19. https://www.ucsf.edu/news/2020/08/418241/aeronabs-promise-powerful-inhalable-protection-against-covid-19. Accessed 20 August 2020.

[111] Zhao J, Zhao J, Perlman S. T cell responses are required for protection from clinical disease and for virus clearance in severe acute respiratory syndrome coronavirus-infected mice. J Virol 2010;84:9318-9325.

[112] Channappanavar R, Zhao J, Perlman S. T cell-mediated immune response to respiratory coronaviruses. Immunol Res 2014;59:118-128.

[113] Diao B, Wang C, Tan Y, Chen X, Liu Y, Ning L, Chen L, et al. Reduction and Functional Exhaustion of T Cells in Patients With Coronavirus Disease 2019 (COVID19). Front Immunol 2020;11:827.

[114] Sekine T, Perez-potti A, Rivera-Ballestros O, Stralin K, Gorin JP, Olsson A, et al Robust $\mathrm{T}$ cell immunity in convalescent individuals with asymptomatic or mild COVID-19 [Article in Press]. Cell 2020.

[115] Boeckh M, Corey L. Adoptive Immunotherapy of Viral Infections: Should Infectious Disease Embrace Cellular Immunotherapy? J Infect 2017;216:926-8 